\title{
Inventory Control Analysis Hospital Bed Manual Unit PI-108MS, PI-208MS, PI-308MS Forecasting and Economic Order Quantity (EOQ) At PT. XYZ
}

\author{
$1^{\text {st }}$ Yusita Attaqwa, $2^{\text {nd }}$ Jihan Pradesi, $3^{\text {rd }}$ Arina Fardiana \\ ${ }^{1.2,3}$ Program Studi Teknik Industri, Fakultas Teknik dan Rekayasa Universitas Selamat Sri \\ 1'yusitattaqwa@gmail.com, ${ }^{2}$ jihan.pradesi@yahoo.com, ${ }^{3}$ arinafrdn@gmail.com
}

\begin{abstract}
Raw material inventory control is a series of things to determine the level of inventory, the time of purchase and the amount of inventory that must be provided. The Economic Order Quantity (EOQ) method is one of the inventory management techniques by considering storage costs and ordering costs. The value is generated by the term reorder point. This value is used to place orders that the company needs to place. 44 units, 68 units, and 36 units are the quantities needed by PT XYZ in every order. So PT XYZ had to do 46 times, 73 times, and 27 unit orders to fulfill their needs.
\end{abstract}

Keywords: Inventory Control, Forecasting, Economic Order Quantity (EOQ)

\section{INTRODUCTION}

Along with the development of manufacturing companies in Indonesia, followed by increasing business competition, of course, requires business people to improve efficiency in all fields. One way to achieve this is by controlling inventory, without inventory, the company is faced with the risk that the company cannot meet customer demands on time.

Raw material inventory control is a series of things to determine the level of inventory, the time of purchase and the amount of inventory that must be provided (Gaur., Saransomrurtai, \& Herjanto, 2015). Raw material inventory control aims to make inventory costs efficient, one way is to make the right purchases according to the production plan so that there are no shortages and excesses in raw material inventory (Renta et al., 2013).

The Economic Order Quantity (EOQ) method is one of the inventory management techniques by considering storage costs and ordering costs. If the total cost is reduced, the optimal order quantity will be obtained (Mardiyanto, 2008). Storage costs are estimated based on the average storage of goods for one year (Indroprasto, 2012).

By using the EOQ method, it can also be calculated safety stock, maximum inventory and also the optimal reorder point for the company so as to avoid shortages or excess inventories.

Forecasting is the art and science of predicting future events. This can be done by using historical data and calculation processes to predict a projection of future events. Another way that can be taken is by subjective intuition or with a mathematical model compiled by the management, (Heizer \& Render, 2011).

Forecasting methods are usually used by the sales department in planning (sales planning) based on the results of sales forecasts, so that forecasting information can be useful for Production Planning and Inventory Control (PPIC) (Fajar \& Hartini, 2020).

\section{RESEARCH METHODS}

Economic Order Quantity is a technique for procuring raw material inventory in a company that determines how many economical orders are for each time an order with a predetermined frequency and when to order again (Riyanto et al, 2001).

\section{RESULTS AND DISCUSSION}

\section{Object of research}

1. PI $108 \mathrm{MS}$

Single crank manual hospital bed, with rigid construction and sophisticated finishing to meet market demands and provide customers with high quality hospital beds.

\section{PI-208 MS}

Two crank manual hospital bed, with rigid construction and soft lining. Equipped with cuttingedge features such as a hip sink, for ergonomic and patient comfort.

3. PI-308 MS

Three crank manual hospital bed, with rigid construction and sophisticated finish. Equipped with cutting edge features such as a hip sink, for ergonomic and patient comfort.

\section{Calculation Results using EOQ}

From the results of calculations using the EOQ Method, Reorder Point, the optimal value is obtained each time an order with a frequency for a year, PT $X Y Z$ predicts their sales will increase from the previous year. In the previous year, PT XYZ required 2,000 units of raw materials in its production process. Price per unit PI- 108 MS RP. 9,675,000, PI 208 MS 
International Journal of Computer and Information System (IJCIS)

Peer Reviewed - International Journal

Vol : Vol. 02, Issue 03, August 2021

e-ISSN : 2745-9659

https://ijcis.net/index.php/ijcis/index

Rp. 10,670,000, PI-308 MS RP. 14,753,000 for this year's PI-208 MS is IDR 10,670,000. For one delivery PT. XYZ requires a fee of IDR 100,000 (courier, insurance, documents, etc.). The calculation of PT XYZ's storage cost is $20 \%$ for each item stored. Then, how much EOQ does the company have?

Number of goods $(R)=2,000$ units

Price per unit $(\mathrm{P})=\mathrm{Rp} .10,670,000$

Ordering cost $(\mathrm{S})=\mathrm{Rp} .1000 .000$

Storage cost $(I)=20 \%$ for each item stored. After that, all you have to do is enter the numbers into the EOQ formula.

$$
\begin{aligned}
E O Q & =\sqrt{\frac{2 \times 2.000 \times 1000.000}{10.670 .000 \times 20 \%}} \\
& =\sqrt{1.874} \\
& =44
\end{aligned}
$$

The value is generated by the term reorder point. This value is used to place orders that the company needs to place. 44 units is the amount needed by PT $\mathrm{XYZ}$ in each order. To find out how many orders PT $\mathrm{XYZ}$ needs in one year, we just need to divide the number of items needed by the number of units per order. Quantity of goods (R): EOQ = number of orders required 2,000:44 $=46$

So PT XYZ has to place 46 orders to fulfill its needs. This method is important for companies to do in maintaining a balance between inventory and required costs.

PT XYZ predicts their sales will increase from the previous year. In the previous year, PT XYZ required 5,000 units of raw materials in its production process. Price per unit PI- 108 MS RP. 9,675,000, PI 208 MS Rp. 10,670,000, PI-308 MS RP. 14,753,000 for this year's PI-108 MS is Rp 9,675,000. For one delivery PT. XYZ requires a fee of IDR 900,000 (courier, insurance, documents, etc.). The calculation of PT XYZ's storage cost is $20 \%$ for each item stored. Then, how much EOQ does the company have?

Number of goods $(R)=5,000$ units

Price per unit $(\mathrm{P})=\mathrm{Rp} .9675,000$

Ordering cost $(\mathrm{S})=\mathrm{Rp} .900,000$

Storage cost $(I)=20 \%$ for each item stored. After that, enter the numbers into the EOQ formula.

$$
E O Q=\sqrt{\frac{2 \times 5.000 \times 900.000}{9.675 .000 \times 20 \%}}
$$

$$
\begin{aligned}
& \sqrt{4.651} \\
= & \\
= & 68
\end{aligned}
$$

The value is generated by the term reorder point. This value is used to place orders that the company needs to place. 68 units is the amount needed by PT $\mathrm{XYZ}$ in each order. To find out how many orders PT $\mathrm{XYZ}$ needs in one year, we just need to divide the number of items needed by the number of units per order. Quantity of goods (R): EOQ = number of orders required. 5,000:68 $=73$

So PT XYZ has to make 73 orders to fulfill its needs. This method is important for companies to do in maintaining a balance between inventory and required costs.

PT XYZ predicts their sales will increase from the previous year. In the previous year, PT XYZ required 1,000 units of raw materials in its production process. Price per unit PI- 108 MS RP. 9,675,000, PI 208 MS Rp. 10,670,000, PI-308 MS RP. 14,753,000 for this year's PI-308 MS is Rp. 14,753,000. For one delivery PT. XYZ requires a fee of IDR 2,000,000 (courier, insurance, documents, etc.). The calculation of PT XYZ's storage cost is $20 \%$ for each item stored. Then, how much EOQ does the company have?

Number of goods $(R)=1000$ units

Price per unit $(\mathrm{P})=\mathrm{Rp} .14,753,000$

Ordering cost $(\mathrm{S})=$ Rp. 2,000,000

Storage cost $(\mathrm{I})=20 \%$ for each item stored. After that, enter the numbers into the EOQ formula.

$$
\begin{aligned}
E O Q & =\sqrt{\frac{2 \times 1.000 \times 2.000 .000}{14.753 .000 \times 20 \%}} \\
& \sqrt{1.355} \\
& =36
\end{aligned}
$$

The value is generated by the term reorder point. This value is used to place orders that the company needs to place. 36 units is the amount needed by PT $\mathrm{XYZ}$ in each order. To find out how many orders PT $\mathrm{XYZ}$ needs in one year, we just need to divide the number of items needed by the number of units per order. Quantity of goods (R): EOQ = number of orders required. $1000: 36=27$

So PT XYZ has to place 27 orders to fulfill its needs. This method is important for companies to do in maintaining a balance between inventory and required costs. 
International Journal of Computer and Information System (IJCIS)

Peer Reviewed - International Journal

Vol : Vol. 02, Issue 03, August 2021

e-ISSN : 2745-9659

https://ijcis.net/index.php/ijcis/index

After knowing the formula for the economic order quantity? Is it important for a company to use it in determining the order size they need. The resulting value is known as the reorder point. This value is used to place orders that the company needs to place.

\section{CONCLUSIONS AND SUGGESTIONS}

\section{Conclusions}

PT. DV MEDIKA Kendal Branch is considering using the Economic Order Quantity Method in purchasing material supplies. Based on the calculations, it is known that by using the Economic Order Quantity method, the Total Cost or the number of Quantity stock units is lower with the Total Cost that must be incurred if the company uses the conventional method. We can conclude that this method seeks to achieve the lowest possible inventory level, followed by low costs. By using the economical order quantity (EOQ) method, the company will be able to minimize the occurrence of out of stock, so that it will not interfere with the production process in a company and can save inventory costs, due to the efficiency of raw material inventory at the company. In order to know when orders can be ordered and how much safety stock there is so that there is no shortage or excess stock. That means the EOQ method is more efficient than the company's conventional method.

And also with the application of the economical order quantity (EOQ) method, the company will be able to reduce costs which include: storage costs, space saving costs (warehouse room and workspace), able to solve inventory accumulation problems, so the risk of that can arise can be reduced due to inventory in the warehouse.

Economic order quantity (EOQ) analysis can also be used easily and practically where in planning how many times materials are purchased and in how many times they are purchased.

\section{Suggestions}

Based on the results of the research and discussion described in the previous chapter, the author gives some suggestions to PT XYZ to pay attention to the layout of the warehouse so that it is more organized and neat so that employees are easier and faster to work on.

\section{REFERENCES}

[1.] Erlina, 2002. Manajemen Persediaan - Jurnal, Program Study Akuntansi, Fakultas Ekonomi, Universitas Sumatera Utara.

[2.] Fajar, M., \& Hartini, S. (2020). Comparison of ARIMA, SSA, and ARIMA-SSA hybrid model performance in Indonesian economic growth forecasting.

[3.] Gaur, S. S., Saransomrurtai, C., \& Herjanto, H. 2015. Top global firms' use of brand profile pages on SNS for marketing communication. Journal of Internet Commerce, 14(3), 316-340.

[4.] Heizer, J., \& Render, B. (2011). Operations management flexible version. Pearson Higher Ed.

[5.] Indroprasto, I., \& Suryani, E. 2012. Analisis Pengendalian Persediaan Produk Dengan Metode EOQ Menggunakan Algoritma Genetika untuk Mengefisiensikan Biaya Persediaan. Jurnal Teknik ITS, 1(1), A305-A309.

[6.] Prihasdi, R. D., \& Rahardjo, S. N. 2012. Efisiensi Metode Economical Order Quantity (EOQ) dalam Pengambilan Keputusan Pembelian Bahan Baku dan Pengaruhnya terhadap Total Biaya Pembelian Pada PT Amitex (Amanah Mitra Industri) Buaran Kabupaten Pekalongan. Diponegoro Journal of Accounting, 1(1), 781-792.

[7.] Renta, N., Waluyo, H. D., \& Nurseto, S. 2013. Analisis Pengendalian Persediaan Bahan Baku Rokok Pada Pt. Gentong Gotri Semarang Guna Meningkatkan Efisiensi Biaya Persediaan. Jurnal Ilmu Administrasi Bisnis, 2(4), 27-34.

[8.] Riyanto, S., Sukari, M. A., Rahmani, M., Ee, G. C., Yap, Y. H. T., Aimi, N., \& Kitajima, M. 2001. Alkaloids from Aegle marmelos (Rutaceae). Malaysian J Anal Sci, 7(2), 463-465. 